\title{
Density of Competition between Species of Urochloa Sp. in Soybean Cultivation
}

\author{
${ }^{1,2}$ Lucas Aparecido Manzani Lisboa, ${ }^{1}$ Ronaldo da Silva Viana, ${ }^{1}$ Victor Garcia Venâncio, ${ }^{1}$ Filipe Virgilio Ribeiro, ${ }^{1}$ Igor \\ Virgilio Ribeiro, ${ }^{1}$ Paulo Alexandre Monteiro de Figueiredo, ${ }^{1}$ Sérgio Bispo Ramos, ${ }^{2}$ Gabriel Banos Rodrigues, ${ }^{2}$ Hiago \\ Augusto Amaral Sacco, ${ }^{1}$ Mateus Augusto Marques Batista
}

${ }^{1}$ São Paulo State University (Unesp), College of Technology and Agricultural Sciences, Dracena, São Paulo, Brazil

${ }^{2}$ Integrated College Stella Maris (FISMA) e Educational Fundation of Andradina (FEA), Andradina, São Paulo, Brazil

Correspondence Author: Lucas Aparecido Manzani Lisboa, 1São Paulo State University (Unesp), College of Technology and Agricultural Sciences, Dracena, São Paulo, Brazil

E-mail: lucas.lisboa@unesp.br

Received date: 12 June 2018, Accepted date: 4 September 2018, Online date: 13 September 2018

Copyright: (C) 2018 Lucas Aparecido Manzani Lisboa, et al, This is an open-access article distributed under the terms of the Creative Commons Attribution License, which permits unrestricted use, distribution, and reproduction in any medium, provided the original author and source are credited.

\begin{abstract}
Introduction: Competition between grasses and legumes in cultivation areas depends on their specific skills of survival. Objective: This work aimed to evaluate effects of densities of competition between species of Uroch loa sp. in soybean cultivation. Material and Methods: The experiment was carried out in a completely randomized design, in a $3 \times 5$ factorial scheme, with 3 different grasses species: Urochloa brizantha cv. Marandu and Piatã and Urochloa ruziziensis; and 5 different densities of grasses, with 5 repetitions, summing 75 plots or vases. Thirty days after sowing, the following variable were set: SPADS - spad index of soybean; SC - stomata conductance; DSS - diameter of soybean stem; HS and HG - height of soybean and height of grass; NSL - number of soybean leaves; DMAPS and DMAPG - dry mass of aerial part of soybean and dry mass of aerial part of grass; and DMSR and DMGR - dry mass of soybeans 'root and dry mass of grass 'root. Conclusion: Urochloa brizantha cv. and Piatã e Urochloa ruziziensis caused a greater harmful effect in soybean cultivation. Development of soybean cultivation is impaired even in low competition with species of Urochloa, being necessary its control at the initial phase of cultivation..
\end{abstract}

Key words: Glycine Max, Grass competition, sowing, stomata conductance, spad

\section{INTRODUCTION}

Soybean (Glycine $\max (\mathrm{L}$.$) Merrill) highlights in Brazilian agricultural sector, because of its importance as source of protein and vegetal oil for food security$ alongside corn, compounding the base of ration formulation for animals. Also, due to the development in human nutrition sector, soybean and corn are used in formulation of different foods. (Costa and Brum, 2008).

During its growing period, soybean is subjected to abiotic stress such as herbivorous animals as well as invasive plants competition. Understanding the involved tools in competition between species is fundamental in agricultural systems, remarkably association between plants with different characteristics. Plants often compete with each other (intraspecific) and with other plants (interspecific) for the environmental resources, in many cases vith the allelopathic effect between species (Nepomuceno et al., 2017; Abdelmigid and Morsi, 2017). Duration of the competition time negatively influences on the development and on the yield of the culture (Almeida et al., 2014).

This competition between plants leads to damages in its physiology, mainly in the decrease in chlorophyll index (Nogueira et al., 2010; Lisboa et al., 2017) and stomata conductance (Jumrani et al., 2017), which initiate a breakdown in the shape and development of soybean. Competition level in grass-culture associations depends on the intervention of factors linked to the weed community, which involves specific composition, distribution, specie, density, phase and duration of intercultural living, as well as depends on climatic conditions and treatments (Figueiredo et al., 2013).

The competition released by weed is named grass competition, a problem that may initiates significant $90 \%$ loss of the yield. It also can cause problems in grains quality. That way, it is important to know the soybean cycle, so that, it is possible to know in which moment the greatest interference of weeds occurs. Managing weeds is an essential step to guarantee higher performances, especially in chemical control, once this is the more practical and efficient method (Franco et al., 2017).

This work aimed to evaluate effects of density of competition between species of Urochloa sp. in soybean cultivation.

\section{MATHERIAL AND METHODS}

Installing the experiment:

The experiment was carried out in the Vegetation House of the College of Technology and Agricultural Sciences, in São Paulo State University (Unesp), in Dracena, Brazil, in October, 2016. A completely randomized design was installed, in a $3 \times 5$ factorial scheme, with 3 different grasses species: Urochloa brizantha cv. Marandu and Piatã and Urochloa ruziziensis; and 5 different densities of grasses, with 5 repetitions, summing 75 plots or vases.

BMX Potência soybean cultivar was used; it was sowed three centimeters deep in vases with $9.0 \mathrm{dm}^{3} \mathrm{capacity}$ and $490.6 \mathrm{~cm}{ }^{2}$ area. All vases were filled with sifted soil, originally classified as Argillaceous Ferric yellow red (Embrapa, 2013), with the following chemical attributes: $\mathrm{pH} \mathrm{CaCl}=4.5 ; \mathrm{MO}_{2} / \mathrm{dm}^{-3}=4.5 ; \mathrm{P}$ $\mathrm{mg} / \mathrm{dm}^{-3}(\mathrm{resin})=6.0 ; \mathrm{K} \mathrm{mmolc} / \mathrm{dm}^{-3}(\mathrm{resin})=4.6 ; \mathrm{Ca} \mathrm{mmolc}_{\mathrm{dm}^{-3}}(\mathrm{resin})=10.0 ; \mathrm{Mg} \mathrm{mmolc}^{-3} \mathrm{dm}^{-3}(\mathrm{resin})=4.0 ; \mathrm{S}(\mathrm{SO} 4-2) \mathrm{mg} / \mathrm{dm}^{-3}=7.0 ; \mathrm{H}+\mathrm{Al} \mathrm{mmol} / \mathrm{dm}^{-3}=18.0 ;$ $\mathrm{Al} \mathrm{mmolc} / \mathrm{dm}^{-3}=1.0$; Sum of bases mmolc/ $\mathrm{dm}^{-3}=15.6$; CTC mmolc/dm ${ }^{-3}=33.6$; Base Saturation $(\mathrm{V} \%)=46.4$ and Saturation Al $(\mathrm{m} \%)=6.0$. Fertilizing of soybean was carried out according to Raij et al. (1996). At the same moment, Urochloa sp. seeds were sowed two centimeters deep. 
Citation: Lucas Aparecido Manzani Lisboa, et al., Density of Competition between Species of Urochloa Sp. in Soybean Cultivation. Australian Journal of Basic and Applied Sciences, 12(9): 35-40. DOI: 10.22587/ajbas.2018.12.9.6

The following densities were used the sowing of grass: absence of grass - just soybean in the pot; low density of grass, with three grasses seeds per pot, providing $163.53 \mathrm{~cm}^{2}$ per plant; normal density, with six grasses seeds per pot, providing $81.76 \mathrm{~cm}^{2}$ per plant; high density, with nine grasses seeds per pot, providing $54.51 \mathrm{~cm}^{2}$ per plant; very high density, with twelve grasses per pot, providing $40.88 \mathrm{~cm}^{2}$ per plant. During the experiment, vases were irrigated whenever necessary, till they reach capacity of land.

Productive variables and Physiological analyzes:

Thirty days after the sowing, the following variables were set: SPADS - spad index of soybean, set from direct reading, by using CCM-200 digital meter; SC - stomata conductance, set from direct reading, by using porometer AP4 device ; DSS - diameter of soybean stem, by using millimeter ruler; HS and HG - height of soybean and height of grass; NSL - number of soybean leaves, by direct counting; DMAPS and DMAPG - dry mass of aerial part of soybean and dry mass of aerial part of grass and DMSR and DMGR - dry mass of soybeans root and dry mass of grass root, by drying the moist matter in oven with circulation and renovation of air, under a steady $65^{\circ} \mathrm{C}$ temperature till they it reach constant weight.

Statistical analyzes:

All variables were submitted to the F test $(\mathrm{p}<0.05)$ and the averages were compared using the Tukey test $(\mathrm{p}<0.05)$, by using Assistat 7.7 static software (Silva and Azevedo, 2016).

\section{RESULTS AND DISCUSSION}

Statistical difference was not observed between the variables regarding to SPADS, as Table 1 shows.

Table 1: Average values of parameter: SPADS - spad index of soybean; SC - stomata conductance; DSS - diameter of soybean stem; HS- height of soybean;; DMAPS - dry mass of aerial part of soybean and DMSR - dry mass of soybean 'root.

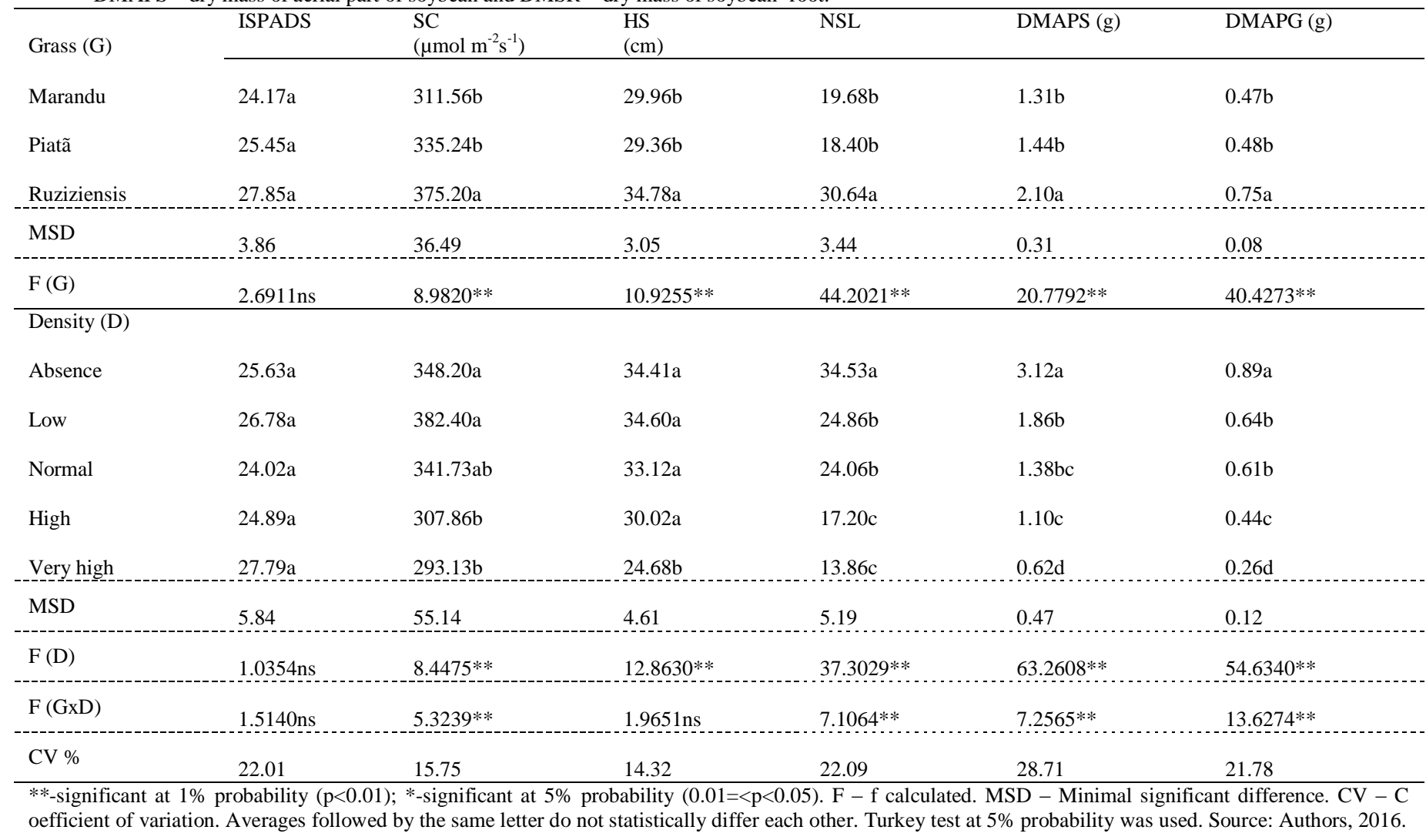

Spad index of soybean shows a high correlation with nitrogen index in the leaves (Nogueira et al., 2010; Parente et al., 2015), others elements also influence on intensity of green color in leaves, as reported by Brahim (2017) and even the number of leaves in its aerial part, which negatively influenced the rate of photosynthesis as well as dry mass accumulation.

Significant interaction was observed in SC of soybeans as submitted to grass competition, as Table 1 shows. Table 2 displays average values of interaction in the SC parameter, as submitted to competition with Urochloas.

Stomata conductance of soybeans was negatively influenced as submitted to grass competition with $U$. brizantha cv. Marandu in high density; this damage was observed just in competition with $U$. brizantha cv. Piatã, which evidences the severity of this grass over soybeans culture. However, reduction in SC of soybeans was not observed as submitted to competition with $U$. ruziziensis.

Weeds may have a better adaptation to changes in concentrations of atmospheric $\mathrm{CO}_{2}$ or even to the environmental conditions that are inserted in competition with other culture (Varanasi et al., 2016). Due to its genetic diversity and greater physiological plasticity, mainly on its transpiration and stomata density, which starts be influenced by environmental variables, this difference directly entail photosynthetic efficiency due to the lower or greater translocation of water, and, consequently, the accumulation of inner $\mathrm{CO}_{2}$ in leaves (Jumrani et al., 2017).

A significant effect was singly observed between the variables regarding the HS, in which $U$. brizantha cv. Marandu and Piatã negatively influenced in the growth of soybean. This effect was observed as soybean was sowed along with grasses into very high density. The growth of soybean stem matched in the absence of grass till the high density of grass or grass competition, which displays an effect of etiolation in the stem, when occurred the necessity of light.

As described by Mckenzie-Gopsill et al. (2016), who also observed the same phenomenon by studying soybean with weed competition submitted to water restriction. These authors reported the plasticity of the more tolerant species as submitted to competitions with other plants. Benaragama et al. (2016) found an invasive plant population of $40 \%$ higher in relation to the conventional organic crop system with a lower production of approximately $50 \%$, showing the necessity of controlling invasive plants in crops.

Again, a significant interaction was observed among the NSL factors as Table 1 demonstrates. Table 3 shows the interaction of the NSL factors as submitted to different densities of competition with grasses. 
Citation: Lucas Aparecido Manzani Lisboa, et al., Density of Competition between Species of Urochloa Sp. in Soybean Cultivation. Australian Journal of Basic and Applied Sciences, 12(9): 35-40. DOI: 10.22587/ajbas.2018.12.9.6

Table 2: Unfolding of interaction of Stomata Conductance of Soybean $\left(\mathrm{SC}-\mu \mathrm{mol} \mathrm{m} \mathrm{s}^{-1}\right)$ as submitted to densities of grass.

Density of grass (D)

\begin{tabular}{|c|c|c|c|c|c|}
\hline Grass (G) & Absence & Low & Normal & High & Very High \\
\hline Marandu & $393.00 \mathrm{abA}$ & $394.20 \mathrm{aA}$ & $347.20 \mathrm{abA}$ & $221.40 \mathrm{bB}$ & $202.00 \mathrm{bB}$ \\
\hline Piatã & $328.00 \mathrm{bAB}$ & $402.00 \mathrm{aA}$ & $293.00 \mathrm{bB}$ & $328.20 \mathrm{aAB}$ & $325.00 \mathrm{aAB}$ \\
\hline Ruziziensis & $413.60 \mathrm{aA}$ & $351.00 \mathrm{aA}$ & $385.00 \mathrm{aA}$ & $374.00 \mathrm{aA}$ & $352.40 \mathrm{aA}$ \\
\hline
\end{tabular}

MSDcol.: 81.59

MSDlin.: 95.51

Averages followed by the same lower-case letters in column do not statistically differ each other. Averages followed by the same capital letters in line do not statistically differ each other. Turkey test at 5\% probability was used. MSD- Minimal significant difference. Source: Authors, 2016.

Table 3: Unfolding of interaction of NSL - number of soybean leaves, as submitted to different densities of competition with grasses.

Density of grass (D)

\begin{tabular}{|c|c|c|c|c|c|}
\hline Grass (G) & Abscence & Low & Normal & High & Very High \\
\hline Marandu & $22.60 \mathrm{bA}$ & $22.20 \mathrm{bA}$ & $21.40 \mathrm{bA}$ & $17.80 \mathrm{aA}$ & $14.40 \mathrm{aA}$ \\
\hline Piatã & $29.80 \mathrm{bA}$ & $20.00 \mathrm{bB}$ & $15.80 \mathrm{bB}$ & $14.40 \mathrm{aB}$ & $12.00 \mathrm{aB}$ \\
\hline Ruziziensis & $51.20 \mathrm{aA}$ & $32.40 \mathrm{aB}$ & $35.00 \mathrm{aB}$ & $19.40 \mathrm{aC}$ & $15.20 \mathrm{aC}$ \\
\hline
\end{tabular}

MSDcol.: 7.69

MSDlin.: 9.00

Averages followed by the same lower-case letters in column do not statistically differ each other. Averages followed by the same capital letters in line do not statistically differ each other. Turkey test at 5\% probability was used. MSD- Minimal significant difference. Source: Authors, 2016.

Soybean culture, under grass competition of $U$. brizantha cv. Marandu, did not suffered harmful effect in any density, however, at low competition with $U$. brizantha cv. Piatã and $U$. ruziziensis, soybean displayed a lower number of leaves, which shows harmful effect caused by the competition between the species.

Because of the lower NSL, its photosynthetic area decreased, which lead to smaller accumulation of carbon in its dry mass, the understanding regarding the damage effects can be explained by Souza et al. (2014), as they evaluated morphophysiological characteristics and yield of soybean in consequence of defoliation at the vegetative stage, they also found a negative influence caused by the reduction of leaves, even in grain production.

Table 4 shows interactions between the factors of the parameter dry mass of aerial part of soybean (DMAPS) as submitted to grass competition.

Table 4: Unfolding of interaction of factors of the parameter dry mass of aerial part of soybean (DMAPS) as submitted to grass competition.

\begin{tabular}{|c|c|c|c|c|c|}
\hline \multirow[b]{2}{*}{ Grass (G) } & \multicolumn{5}{|c|}{ Density of grass (D) } \\
\hline & Abscence & Low & Normal & High & Very High \\
\hline Marandu & $1.79 \mathrm{bA}$ & $2.06 \mathrm{aA}$ & $1.28 \mathrm{bAB}$ & $0.85 \mathrm{aB}$ & $0.56 \mathrm{aB}$ \\
\hline Piatã & $3.59 \mathrm{aA}$ & $1.41 \mathrm{aB}$ & $0.73 \mathrm{bBC}$ & $1.00 \mathrm{aBC}$ & $0.47 \mathrm{aC}$ \\
\hline \multirow[t]{2}{*}{ Ruziziensis } & $4.00 \mathrm{aA}$ & $2.10 \mathrm{aB}$ & $2.13 \mathrm{aB}$ & $1.45 \mathrm{aBC}$ & $0.82 \mathrm{aC}$ \\
\hline & \multicolumn{2}{|c|}{ MSDcol.: 0.70} & \multicolumn{3}{|c|}{ MSDlin.: 0.82} \\
\hline
\end{tabular}

Averages followed by the same lower-case letters in column do not statistically differ each other. Averages followed by the same capital letters in line do not

statistically differ each other. Turkey test at 5\% probability was used. MSD- Minimal significant difference. Source: Authors, 2016.

Soybean suffered a harmful effect caused by competition between species as submitted to high competition with $U$. brizantha cv. Marandu, to $U$. brizantha cv. Piatã and U. ruziziensis, this negative effect occurred from the low density, which evidences a lower competition caused by $U$. brizantha cv. Marandu as compared to others studied grass species.

These results prove that culture of soybean is highly responsive in negative way to the effect of competition between the species, mainly regarding the light, water and nutrients (Brahim et al., 2017), where metabolism of the plant was impaired and, consequently, the accumulation of DMAPS (Heemst, 1985). Plasticity of adaptation of soybean under competition with others species is varied, as reported by Mckenzie-Gopsill et al. (2016), these adaptation or modification reach, in general, the vegetal organism, even at tissues 'level of the organs.

In the same way, dry mass of soybeans roots (DMSR) also shows restrictive growth effect caused by competition with grass species (Table 5).

Independently of $U$. brizantha cv. Marandu density, it did not influence on growth of soybean roots, however, as soybean was sowed along with grass $U$. brizantha cv. Piatã and $U$. ruziziensis, a harmful effect was observed from the low density of sowing, displaying competition between the species.

Performance of $U$. ruziziensis along with soybean culture, observed competition effect between species, mainly in the running for light, once this interference limits photosynthetic rate, resulting in a decrease of dry mass of cultures under grass competition (Silva et al., 2013).

In isolation, a statistical difference was observed between the factor in the HG (height of grass), as Table 6 shows. U. ruziziensis showed a lower average value to this variable with an approximated $8.78 \%$ difference. As, to the density of grass, its height was negatively influenced even in low density.

The culture of corn along with $U$. ruziziensis, verified that the density of sowing influenced on the development of the grass, which, in the same way, occurred with Urochloa sp. in this work, in which it developed at low density and, consequently, affects the growth of soybean as well as each other (Freitas et al., 2013). In this sense, Datta et al. (2017), by studying the arrangement of the spaces and densities in sowing of soybean, verified that the population decreased as well as the development of the grass. 
Citation: Lucas Aparecido Manzani Lisboa, et al., Density of Competition between Species of Urochloa Sp. in Soybean Cultivation. Australian Journal of Basic and Applied Sciences, 12(9): 35-40. DOI: 10.22587/ajbas.2018.12.9.6

There was a significant interaction between the factors in the dry mass variable of the aerial part of the grass, as Table 6 shows. At normal sowing density, the grasses $U$. brizantha cv. Marandu and Piatã presented lower average values, as U. ruziziensis presented the lowest values only at a low seed density, as Table 7 shows.

Table 5: Unfolding of interaction of factors of the parameter DMGR - dry mass of soybeans 'root as submitted to grass competition.

Density of grass (D)

\begin{tabular}{|c|c|c|c|c|c|}
\hline Grass (G) & Abscence & Low & Normal & High & Very High \\
\hline Marandu & $0.42 \mathrm{cA}$ & $0.57 \mathrm{bA}$ & $0.56 \mathrm{bA}$ & $0.44 \mathrm{abA}$ & $0.39 \mathrm{aA}$ \\
\hline Piatã & $0.95 \mathrm{bA}$ & $0.55 \mathrm{bB}$ & $0.44 \mathrm{bBC}$ & $0.32 \mathrm{bCD}$ & $0.17 \mathrm{bD}$ \\
\hline Ruziziensis & $1.29 \mathrm{aA}$ & $0.82 \mathrm{aB}$ & $0.85 \mathrm{aB}$ & $0.55 \mathrm{aC}$ & $0.24 \mathrm{abD}$ \\
\hline
\end{tabular}

MSDcol.: $0.18 \quad$ MSDlin.: 0.21

Averages followed by the same lower-case letters in column do not statistically differ each other. Averages followed by the same capital letters in line do not statistically differ each other. Turkey test at 5\% probability was used. MSD- Minimal significant difference. Source: Authors, 2016.

Table 6: Average values of the evaluated parameters, HS - height of grass, DMAPG - dry mass of aerial part of grass and DMGR - dry mass of grass' root.

\begin{tabular}{|c|c|c|c|}
\hline Grass (G) & $\mathrm{HG}(\mathrm{cm})$ & DMAPG (g) & DMGR $(\mathrm{g})$ \\
\hline Marandu & $66.37 \mathrm{a}$ & $11.27 \mathrm{a}$ & $10.41 \mathrm{a}$ \\
\hline Piatã & $67.15 \mathrm{a}$ & $10.13 a$ & $8.59 b$ \\
\hline Ruziziensis & $61.25 \mathrm{~b}$ & $10.83 \mathrm{a}$ & $8.17 \mathrm{~b}$ \\
\hline SD & 5.01 & 1.86 & 1.48 \\
\hline$F(G)$ & $4.7828 *$ & $1.1051 \mathrm{~ns}$ & $7.4947 * *$ \\
\hline \multicolumn{4}{|l|}{ Density (D) } \\
\hline Low & 63.01ab & $5.93 \mathrm{c}$ & $4.72 \mathrm{c}$ \\
\hline Normal & $68.36 \mathrm{a}$ & $9.63 b$ & $7.92 \mathrm{~b}$ \\
\hline High & $67.00 \mathrm{ab}$ & $14.27 \mathrm{a}$ & $11.97 \mathrm{a}$ \\
\hline Very High & $61.31 \mathrm{~b}$ & $13.15 \mathrm{a}$ & $11.63 \mathrm{a}$ \\
\hline MSD & 6.37 & 2.36 & 1.88 \\
\hline $\mathrm{F}(\mathrm{D})$ & $3.8238^{*}$ & $35.9295^{* *}$ & $46.8178^{* * *}$ \\
\hline $\mathrm{F}(\mathrm{GxD})$ & $1.2402 \mathrm{~ns}$ & $2.8102 *$ & $2.4397 *$ \\
\hline $\mathrm{CV} \%$ & 10.09 & 22.68 & 21.40 \\
\hline
\end{tabular}

Table 7: Unfolding of interaction of factors in the parameter DMAPG - dry mass of aerial part of grass, as submitted to grass competition.

\begin{tabular}{|c|c|c|c|c|}
\hline \multirow[b]{2}{*}{ Grass (G) } & \multicolumn{4}{|c|}{ Density of grass (D) } \\
\hline & Low & Normal & High & Very High \\
\hline Marandu & $7.90 \mathrm{aB}$ & $8.12 \mathrm{aB}$ & $13.53 \mathrm{aA}$ & $15.54 \mathrm{aA}$ \\
\hline Piatã & $4.51 \mathrm{aC}$ & $9.84 \mathrm{aB}$ & $15.29 \mathrm{aA}$ & $10.90 \mathrm{bB}$ \\
\hline Ruziziensis & $5.37 \mathrm{aB}$ & $10.92 \mathrm{aA}$ & $13.99 \mathrm{aA}$ & $13.02 \mathrm{abA}$ \\
\hline
\end{tabular}

DMScol: $3.72 \quad$ DMSlin.: 4.10

Averages followed by the same lower-case letters in column do not statistically differ each other. Averages followed by the same capital letters in line do not statistically differ each other. Turkey test at 5\% probability was used. MSD- Minimal significant difference. Source: Authors, 2016.

These results were expected, because of the bigger amount of grass, it occurred a greater accumulation of dry mass in aerial part. However, it necessary remarking that this increase is directly linked to the number of plants till the point in which there is no competition each other, that may be a limiting factor to it development. 
Medeiros et al. (2016) reported that a grassy weed presents a higher capacity in extraction of soil micronutrients, which is an important adaptation to their environment, even in competitions with big cultures, as Eucalyptus. With a greater extraction of nutrients, its growth can be beneficed, but, with competition each other, it is limiting factor to accumulation of mass in its aerial part or root. Nowadays, Urochloa grasses are widely used aiming dry mass to no-till farming of soybean culture, as reported by Balbinot et al. (2016). It is remarkable that is necessary an efficient desiccation to avoid the presence of grasses competing with the soybean culture.

Similarly to variable DMAPG, DMGR presented a significant interaction between the factors, as Table 6 shows.

Table 8 shows unfolding of interaction of factors in the parameter DMGR as submitted to grasses competition, in which is observed that in a normal density of grass, $U$. brizantha cv. Marandu and Piatã presented lower average values, as U. ruziziensis presented lowest values in low density of grass.

Table 8: Unfolding of interaction of factors in the parameter DMGR - dry mass of grass' root as submitted to grass competition.

Density of grass (D)

\begin{tabular}{|c|c|c|c|c|}
\hline Grass (G) & Low & Normal & High & Very high \\
\hline Marandu & $6.61 \mathrm{aB}$ & $7.51 \mathrm{aB}$ & $12.76 \mathrm{aA}$ & $14.75 \mathrm{aA}$ \\
\hline Piatã & $3.79 \mathrm{aC}$ & $8.50 \mathrm{aB}$ & $12.19 \mathrm{aA}$ & $9.90 \mathrm{bAB}$ \\
\hline Ruziziensis & $3.75 \mathrm{aB}$ & $7.75 \mathrm{aA}$ & $10.95 \mathrm{aA}$ & $10.23 \mathrm{bA}$ \\
\hline
\end{tabular}

Averages followed by the same lower-case letters in column do not statistically differ each other. Averages followed by the same capital letters in line do not statistically differ each other. Turkey test at 5\% probability was used. MSD- Minimal significant difference. Source: Authors, 2016.

Good development of root is essential to the establishment of the culture in its substrate, guaranteeing greater nutrients and water absorption, which also promotes good development of the aerial part. Plants with bigger index of roots in soil, guarantees greater resistance to water stress during summer (Castro et al., 2009). This harmful effect caused by the competition between the same or others species, as Table 1 shows. Development of soybean roots was impaired by the competition for space with other grasses. Understanding the responses of the culture under grass competition is an important tool in decision-making process at the control of invasive plants, aiming the maximum yield of soybean culture (Lisboa et al., 2017).

Conclusion:

Urochloa brizantha cv. and Piatã and Urochloa ruziziensis caused a greater harmful effect in soybean cultivation. The development of soybean cultivation is impaired even in low competition with species of Urochloa, being necessary its control at the initial phase of cultivation.

\section{REFERENCES}

Abdelmigid, H.M., M.M. Morsi, 2017. Cytotoxic and molecular impacts of allelopathic effects of leaf residues ofEucalyptus globulus on soybean (Glycine max). Journal of Genetic Engineering and Biotechnology, 15(2): 297-302. https://doi.org/10.1016/j.jgeb.2017.08.005

Almeida, M.O., E.A. Ferreira, D.V. Silva, J.B. Santos, R.B. Rodrigues, B.P. Souza, S.S.D. Costa, 2014. Influence of the cup size and time of evaluation on growth black jack in competition with corn and soybean. Bioscience Journal, 30(5): 1428-1437. (in Portuguese)

Balbinot Junior, A.A., J.C. Franchini, H. Debiasi, 2016. Sward height management, desiccation time of Urochloa ruziziensis and nitrogen fertilization of soybean under crop-livestock system. Revista de Ciências Agroveterinárias, 15(2): 124-133. (in Portuguese) http://dx.doi.org/10.5965/223811711522016124

Benaragama, D., S.J. Shirtliffe, E.N. Johnson, H.S.N. Duddu, L.D. Syrovy, 2016. Does yield loss due to weed competition differ between organic and conventional cropping systems?. European Weed Research Society, 56: 274-283. http://dx.doi.org/10.1111/wre.12213

Brahim, S., A. Niess, M. Pflipsen, D. Neuhoff, H. Scherer, 2017. Effect of combined fertilization with rock phosphate and elemental sulphur on yield and nutrient uptake of soybean. Plant Soil Environ, 63(2): 89-95. http://dx.doi.org/10.17221/22/2017-PSE

Castro, E.M., F.J. Pereira, R. Paiva, 2009. Histologia vegetal: estrutura e função de órgãos vegetativos. UFLA. (in Portuguese)

Costa, N.L., A.L. Brum, 2008. Aspectos recentes da economia da soja no Brasil. In: BRUM, A. L.; MÜLLER, P. K. (Eds.). Aspectos do agronegócio no Brasil. Ijuí: Unijuí, 197-223. (in Portuguese)

Datta, A., H. Ullah, N. Tursun, T. Pornprom, S.Z. Knezevic, B.S. Chauhan, 2017. Managing weeds using crop competition in soybean [Glycine max (L.) Merr.], Crop Protection, 95: 60-68. http://dx.doi.org/10.1016/j.cropro.2016.09.005

Empresa Brasileira de Pesquisa Agropecuária - EMBRAPA, 2013. Sistema brasileiro de classificação de solos. 3.ed. Brasília. (in Portuguese)

Figueiredo, P.A.M., S.B. Ramos, R.S. Viana, L.A.M. Lisboa, R. Heinrichs, 2013. Morph anatomical changes of sugar cane leaves in phase of establishment under weed competition. Planta Daninha, 31(4): 777-784. (in Portuguese) https://dx.doi.org/10.1590/S0100-83582013000400003

Franco, J.J., D. Agostinetto, A.C. Langaro, L.T. Perboni, L. Vargas, 2017. Relative competitiveness of goose grass biotypes and soybean crops. Revista Caatinga, 30(2): 271-277. http://dx.doi.org/10.1590/1983-21252017v30n201rc

Freitas, R.J., A.S. Nascente, F.L.S. Santos, 2013. Population of maize plants intercropped with Urochloa ruziziensis. Pesquisa Agropecuária Tropical, 43(1): 79-87. (in Portuguese) http://dx.doi.org/10.1590/S1983-40632013000100011

Heemst, H.D., 1985. The Influence of Weed Competition on Crop Yield. Agricultural Systems. 18: 81-93. https://doi.org/10.1016/0308-521X(85)90047-2

Horneburg, B., S. Seiffert, J. Schmidt, M.M. Messmer, K. Wilbois, 2017. Weed tolerance in soybean: a direct selection system. Plant Breeding, 1-7. http://dx.doi.org/10.1111/pbr.12469

Jumrani, K., V.S. Bhatia, G.P. Pandey, 2017. Impact of elevated temperatures on specific leaf weight, stomatal density, photosynthesis and chlorophyll fluorescence in soybean. Photosynthesis Research, 131(3): 333-350. http://dx.doi.org/10.1007/s11120-016-0326-y

Lisboa, L.A.M., R.S. Viana, S. Ferrari, V.G. Venâncio, P.A.M. Figueiredo, 2017. Initial development of cotton when submitted to grass competition. Colloquium Agrariae, 13(3): 88-97. (in Portuguese) http://dx.doi.org/10.5747/ca.2017.v13.n3.a177

Mckenzie-Gopsill, A.G., L. Lukens, E. Lee, C.J. Swanton, 2016. Does the presence of neighbouring weeds alter the expression of adaptive plasticity to subsequent drought stress in soybean?. Field Crops Research, 192: 144-153. http://dx.doi.org/10.1016/j.fcr.2016.04.029

Medeiros, W.N., C.A.D. Melo, R.A.S. Tiburcio, G.S. Silva, A.F.L. Machado, L.D.T. Santos and F.A. Ferreira, 2016. Initial growth and nutrient concentration in Eucalyptus urophylla x Eucalyptus grandis clones under weed interference. Ciência Florestal, 26(1): 147-157. (in Portuguese) http://dx.doi.org/10.5902/1980509821099

Nepomuceno, M., N. Chinchilla, M., Rosa, R.M., Varela, and J.M.G., Molinillo, 2017. Chemical evidence for the effect of Urochloa ruziziensison glyphosate-resistant soybeans. Pest Management Science, 73: 2071-2078 https://doi.org/10.1002/ps.4578 
Nogueira, P.D.M., D.G. Sena Júnior, V.A. Ragagnin, 2010. Leaf chlorophyll and nodulation in soybean with sidedress nitrogen fertilization. Global science and technology, 3(2): 117-124. (in Portuguese)

Parente, T.L., L. Edson, S. Caioni, R.S. Pivetta, L.G.M. Souza, J.W. Bossolani, 2015. Nitrogen fertilization at soybean genotypes associated with inoculation in no-tillage in the Savannah. Revista Brasileira de Ciências Agrárias, 10(2): 249-255. (in Portuguese) http://dx.doi.org/10.5039/agraria.v10i2a5320

Raij, B., H. Cantarella, J.Á. Quaggio, A.M.C. Furlani, 1996. Recomendações de adubação e calagem para o Estado de São Paulo. 2. ed. Campinas: IAC. (Boletim Técnico, 100). (in Portuguese)

Silva, F.A.Z., C.A.V. Azevedo, 2016. The Assistat Software Version 7.7 and its use in the analysis of experimental data. African Journal Agriculture Resarch, 11(39): 3733-3740. http://dx.doi.org/10.5897/AJAR2016.11522

Silva, W.B., F.A. Petter, L.B. Lima, F.R. Andrade, 2013. Initial development of Urochloa ruziziensis and agronomic performance of soybean in different space arrangements in the cerrado of Mato Grosso, Brazil. Bragantia, 72(2): 146-153. (in Portuguese) http://dx.doi.org/10.1590/S0006-87052013000200006

Souza, V.Q., M. Nardino, D.N. Follmann, C.A. Bahry, B.O. Caron, P.D. Zimmer, 2014. Morphophysiological characters and soybean yield due to defoliation at vegetative stage. Científica, 42(3): 216-223. (in Portuguese)

Varanasi, A., P.V.V. Prasad, M. Jugulam, 2016. Impact of climate change factors on weeds and herbicide efficacy. Advances in Agronomy, 135: 107-146. http://dx.doi.org/10.1016/bs.agron.2015.09.002 